\title{
Postać Dawida w hebrajskiej wersji Psalmu 151 (11Q5)
}

\author{
The Figure of David in the Hebrew Version of Psalm 151 (11Q5)
}

\author{
KS. MARCIN BIEGAS \\ Instytut Nauk Biblijnych, Katolicki Uniwersytet Lubelski Jana Pawła II \\ e-mail: m.biegas@icloud.com \\ ORCID: 0000-0002-9860-2653
}

\begin{abstract}
Summary: Until the discovery of Qumran scrolls, Psalm 151 was known only through its Greek and Latin versions that make part of the Book of Psalms in the Septuagint and Vulgate respectively. A Syriac translation included in the Apocryphal Psalms of the Syriac collection from the 10th century was also known. In 1965 James Sanders published the Psalm Scroll, a collection of mostly Hebrew Masoretic psalms found in Qumran Cave 11, together with the Hebrew text of Ps 151 that makes part of the scroll. This article focuses on the figure of David depicted in Psalm 151 which in the poetic form retells the story of the son of Jesse found in 1 Samuel, chapters 16 and 17. The article is divided into two parts. In the first one, we describe the scroll and give a general overview of the scholarly discussion concerning the psalm. The second part contains the Hebrew text of Psalm 151 and its Polish translation together with the linguistic, syntactical and theological analyses followed by a brief summing up.
\end{abstract}

Keywords: David, Scrolls, Qumran,11Q5, Psalm 151

SŁowa Kluczowe: Dawid, zwój, Qumran, 11Q5, Psalm 151

$\mathrm{T}$

erytorium dzisiejszego Izraela nie było miejscem zasobnym w zabytki piśmiennicze z dawnych epok. Patrząc na Irak czy Egipt, gdzie wykopaliska dostarczyły niezliczoną ilość tekstów, Palestyna nie mogła poszczycić się czymś podobnym aż do 1947 r. Wcześniej krążyły niepewne pogłoski, że w ubiegłych stuleciach nieopodal Jerycha nad Morzem Martwym odnaleziono jakieś rękopisy ${ }^{1}$.

1 J.C. VanderKam, Manuskrypty znad Morza Martwego (Warszawa: Wydawnictwo Cyklady 1996) 13. Zacytowany autor wyjaśnia, iż Orygenes, komponując swoje dzieło nazywane „Hexaplą”, w 6. greckiej wersji Psalmów użył tekstów znalezionych w dzbanie w pobliżu Jerycha. Dalej przytacza wypowiedź Euzebiusza, historyka Kościoła, żyjącego w latach 260-340 n.e., który w swoim dziele zatytułowanym „Historia Kościoła” wzmiankuje, że pewna grecka wersja Psalmów oraz inne greckie i hebrajskie rękopisy zostały znalezione w dzbanie w pobliżu Jerycha za panowania rzymskiego cesarza Karakalli. Około 800 r. Tymoteusz I, nestoriański patriarcha Seleucji, napisał list do Sergiusza, metropolity Elamu, w którym zapisał, iż pies pewnego Araba podczas polowania wpadł do jednej z jaskiń i nie wyszedł. Właściciel wszedł za nim i znalazł izbę, w której było wiele ksiąg. Myśliwy udał się do Jerozolimy i opowiedział to Żydom, którzy przybyli tłumnie i znaleźli księgi (m.in. Starego Testamentu) w języku hebrajskim. 
W tym roku rozpoczęto w Qumran profesjonalne prace, dzięki którym przez następne lata odkryto szereg rękopisów i artefaktów².

W niniejszym artykule postaramy się ukazać, w jaki sposób przedstawiony jest Dawid w Psalmie 151, wchodzącym w skład Zwoju Psalmów z groty jedenastej. Dla przejrzystości poniższej pracy podzielimy ją na dwie części. W pierwszej nasza uwaga będzie skupiona na samym manuskrypcie, a więc środowisku naszego psalmu, by pokazać jego treść, układ poszczególnych kompozycji oraz odpowiedzieć na podstawowe pytania: kiedy został spisany, co zawiera, kiedy go odnaleziono oraz kto opracował jego wydanie krytyczne? Na zakończenie części pierwszej przywołamy dyskusję nad funkcją rękopisu w osadzie Esseńczyków, wynikłej tuż po jego publikacji.

Drugą część rozpoczniemy od zamieszczenia oryginalnego hebrajskiego tekstu wraz z jego tłumaczeniem na język polski, po czym przedstawimy strukturę, na której oprzemy dalszą refleksję egzegetyczno-teologiczną. Dla zachowania porządku przy lokalizacji tekstów w zwoju użyjemy oznaczeń, które opracował J.A. Sanders ${ }^{3}$, a co za tym idzie - nie będziemy uwzględniać podziału zaproponowanego przez U. Dahmena ${ }^{4}$.

\section{Zwój Psalmów 11QPsa}

\subsection{Informacje wstępne}

Wspomniany Zwój Psalmów, który w różnych opracowaniach ma dwa warianty skróconego zapisu 11Q5 lub 11Q Ps ${ }^{\mathrm{a}}$, został znaleziony w grocie jedenastej przez jednego z Beduinów na początku lutego 1956 r. Po dostarczeniu go do Muzeum Archeologicznego w Jerozolimie pracownicy zidentyfikowali cztery inne fragmenty oddzielone od zwoju, które według ich badań, były pierwotnie jego częścią; świadczy o tym podobieństwo pisma oraz identyczny materiał, z którego powstał zwój i wspomniane fragmenty ${ }^{\circ}$. Pomiędzy dziesiątym a dwudziestym

2 Por. J. Magness, The Archaeology of Qumran and the Dead Sea Scrolls (Grand Rapids, MI: W.B. Erdmans 2002).

3 Por. J.A. Sanders, The Psalms Scroll of Qumran Cave $11\left(11 Q P s^{a}\right)$ (Discoveries in the Judaean Desert of Jordan IV; Oxford: Clarendon Press 1965).

4 Por. U. Dahmen, Psalmen - und Psalter rezeption im Fruhjudentum. Rekonstruktion, Textbestand, Struktur und Pragmatik der Psalmenrolle 11QPs ${ }^{a}$ aus Qumran (Leiden - Boston: Brill 2003).

5 Por. Sanders, The Psalms Scroll of Qumran Cave 11, 3; Por. J. VanderKam - P. Flint, The Meaning of the Dead Sea Scrolls. Their Significance for Understanding the Bible, Judaism, Jesus, and Christianity (New York: Harper Collins Publishers 2002) 3-33, 120-127; E.D. Reymond, New Idioms within Old. Poetry and Parallelism in the Non-Masoretic Poems of 11Q5 (=11QPs $\left.{ }^{a}\right)$ (Society of Biblical Literature. Early Judaism and Its Literature 31; Atlanta: Scholars Press 
listopada 1961 r. manuskrypt został rozwinięty po raz pierwszy od odkrycia. W 1965 r. J. Sanders opracował pierwsze wydanie krytyczne zwoju 11QPs ${ }^{\mathrm{a}}$ w wielotomowej serii Discoveries in the Judean Desert of Jordan, wydawanej przez Oxford University Press ${ }^{6}$. Na przełomie 2002 i 2003 r. niemiecki egzegeta U. Dahmen przedstawił nową rekonstrukcję z wydaniem krytycznym, które w dużej mierze zostało oparte na pracy Sandersa ${ }^{7}$. Szczegółowa analiza manuskryptu pokazała, iż został spisany na skórze pochodzenia zwierzęcego ${ }^{8}$ o barwie żółto-brązowej. Górna część zwoju, giętka i elastyczna, zachowała się bardzo dobrze, natomiast dolna, krucha i popękana, wykazuje wiele ubytków powstałych na skutek czynników naturalnych. Od prawej do lewej krawędzi zwój mierzy 4 metry i 112 milimetrów długości ${ }^{9}$. Dahmen uważa, iż biorąc pod uwagę kompozycje, które pierwotnie wchodziły w skład zwoju, jego długość mogła wynosić pomiędzy 5,30 a 5,60 $\mathrm{m}^{10}$.

Trudniejsze jest określenie szerokości ze względu na wspomniane braki w okolicy dolnego marginesu, jednak biorąc pod uwagę zapis Psalmu 119, który jest akrostychem, można wywnioskować, iż zwój mógł mierzyć 25-26 centymetrów szerokości ${ }^{11}$. Ubytki w dolnej części zwoju to nie jedyny problem, ponieważ dodatkowy kłopot przy rekonstrukcji sprawił początek manuskryptu, który przetrwał w 5 fragmentach oddzielonych od całości rękopisu: A, B, C I, C II, D. Dalsza część zachowała się bardzo dobrze i nie przysporzyła badaczom większych problemów podczas rekonstrukcji. By wyjaśnić, dlaczego początek jest tak zniszczony, uczeni przyjmują dziś dwie hipotezy. Pierwszą z nich jest wpływ czynników naturalnych na pergamin leżący w grocie przez kilka stuleci. Druga zawiera dwie możliwe przyczyny uszkodzenia manuskryptu: 1) naruszenie początku zwoju przez częste używanie w osadzie Esseńczyków; 2) sprzedaż

2011) 2-18; J.A. Fitzmyer, The Dead Sea Scrolls and the Christian Origins (Grand Rapids, MI: W.B. Erdmans 2000); P.W. Flint, „Psalms and Psalters in the Dead Sea Scrolls”, The Bible and the Dead Sea Scrolls. Scripture and the Scrolls. I: The Second Princeton Symposium on Judaism and Christian Origins (red. J.H. Charlesworth) (Waco, TX: Baylor University Press 2006); tenże, The Dead Sea Psalms Scrolls and the Book of Pslams (STDJ 17; Leiden - New York - Köln: Brill 1997) 39-43.

6 Por. A.C Witt, „David, the «Ruler of the Sons of His Covenant» [...]: The Expansion of Psalm 151 in 11QPsa”, JESOT 3/1 (2014) 77; Wspomniane opracowanie krytyczne znajduje się w 4. tomie: Sanders, The Psalms Scroll of Qumran Cave 11, 18-49.

7 Rekonstrukcja i wydanie krytyczne manuskryptu jest pracą habilitacyjną Dahmena; Dahmen, Psalmen - und Psalter, 39-100.

8 Sanders, The Psalms Scroll of Qumran Cave 11, 3: „P.W. Skehan has suggested it may be calf skin rather than the accustomed goat skin of Qumran".

9 Mimo imponujących rozmiarów, nie jest to najdłuższy manuskrypt, ponieważ znacznie okazalszy jest Zwój Izajasza odnaleziony w „Pierwszej Grocie”, liczący ponad 7 metrów, por. P.W. Flint - E. Ulrich, Qumran Cave 1.II: The Isaiah Scrolls (Discoveries in the Judaean Desert XXXII; Oxford: Clarendon 2010).

10 Por. Dahmen, Psalmen - und Psalter, 25.

11 Por. Sanders, The Psalms Scroll of Qumran Cave 11, 4-5; Dahmen, Psalmen - und Psalter, 25. 
pociętych elementów manuskryptów przez Beduinów ${ }^{12}$. Obie są zasadne, lecz za przyjęciem pierwszej świadczy zdjęcie wykonane tuż po odkryciu manuskryptu, na którym ewidentnie widać silne zanieczyszczenia zewnętrznej części zwoju dyskwalifikujące możliwość ewentualnego, wcześniejszego otwarcia go przez Beduinów.

\subsection{Datacja}

Dokładny przedział czasowy powstania zwoju oparty jest na datacji paleograficznej. J. Sanders, badając sposób zapisu spółgłosek hebrajskich w manuskrypcie, doszedł do wniosku, iż niektóre charakteryzuje styl epoki Hasmonejskiej, natomiast znakomita większość przypomina zapis z epoki Herodiańskiej. Dzięki tej analizie Sanders za czas powstania 11QPs a przyjął pierwszą połowę I stulecia naszej ery ${ }^{13}$. Jego zdanie podziela wielu egzegetów, którzy proponują datację na okres pomiędzy 30 a 50 r. po $\mathrm{Chr}{ }^{14}$

\subsection{Ortografia}

Osobliwy przypadek stanowi kwestia ortografii ${ }^{15}$. Rękopis prezentuje zapis pełny (scriptio plena), a więc tam, gdzie to możliwe, autor używa dwóch hebrajskich półsamogłosek: waw i yod jako matres lectionis. Nie jest to jednak reguła, by można powiedzieć, iż w całym zwoju mamy do czynienia z pełnym zapisem, gdyż w kilku miejscach możemy zauważyć niekonsekwencję autora, który używa również scriptio defectiva ${ }^{16}$.

Trudność sprawia rozróżnienie pisowni półsamogłosek waw i yod zwłaszcza tam, gdzie występują w rdzeniu obok siebie. Można to zauważyć w 135 miejscach:

12 Por. Dahmen, Psalmen - und Psalter, 32-33.

13 Sanders analizuje kolejno każdą z liter hebrajskiego alfabetu, zwracając uwagę na najmniejsze detale, Sanders, The Psalms Scroll of Qumran Cave 11, 6-9.

14 Por. Dahmen, Psalmen - und Psalter, 26; Flint, „Psalms and Psalters in the Dead Sea Scrolls”, 141-149; Witt, „David, the «Ruler of the Sons of His Covenant»”, 77.

15 Por. E. Tov, Textual Criticism of the Hebrew Bible (Second Revised Edition; Minneapolis - Assen: Fortress -Royal van Gorcum 2001) 100-117; tenże, Textual Criticism of the Hebrew Bible, Qumran, Septuagint. Collected Essays (Supplements to Vetus Testamentum 167; Leiden - Boston: Brill 2015) III, 289- 296; E.D. Reymond, Qumran Hebrew. An Overviev of Orthography, Phonology, and Morphology (Society of Biblical Literature 76; Atlanta: Scholars Press 2014) 22-63.

16 Dahmen, Psalmen - und Psalter, 27: „Diese Schriften zeichnen sich u.a. aus durch besonders haufige Plene-Schreibung, haufige Verwendung von matres lectionis, morphologisch durch Langformen der sPP und ePP und Langformen bei bestimmten Verbalformen und durch bestimme Praktiken wie z.B. das Schreiben des Tetragramms in paläohebräischen Buchstaben. All dies ist aber nicht immer konsequent durchgehalten". 
109 razy yod jest krótsze; 17 razy obie spółgłoski mają tę samą długość, natomiast 9 razy yod jest dłuższe od waw. Dla przykładu, w kolumnie XXVII znajduje się „Kompozycja Dawida”, która rozpoczyna się od wprowadzenia sekwencji narracyjnej czasu przeszłego przez wyhy. W tym wypadku długość pierwszych dwóch spółgłosek rdzenia jest identyczna, przy czym normalny zapis powinien zawierać dłuższą waw i zdecydowanie krótszą yod ${ }^{17}$.

\subsection{Zawartość}

Dzięki dokonanej rekonstrukcji przez wspomnianego wyżej J. Sandersa możemy wyróżnić w zwoju następujące teksty:

Fragmenty A, B, C I. Ps 101,1-8; 102,1-2.

Fragment C II. Ps 102,18-29; 103,1.

Fragment D. Ps 109,21-31.

Kolumna I. Ps 105,25-45.

Kolumna II. Ps 146,9-10; 148,1-12.

Kolumna III. Ps 121,1-8; 122,1-9; 123,1-2.

Kolumna IV. Ps 124,7-8; 124,1-5; 126,1-6; 127,1.

Kolumna V. Ps 128,4-6; 129,1-8; 130,1-8; 131,1.

Kolumna VI. Ps 132,8-18; 119,1-6.

Kolumna VII. Ps 119,15-28.

Kolumna VIII. Ps 119,37-49.

Kolumna IX. Ps 119,59-73.

Kolumna X. Ps 119,82-96.

Kolumna XI. Ps 119,105-120.

Kolumna XII. Ps 119,128-142.

Kolumna XIII. Ps 119,150-164.

Kolumna XIV. Ps 119,171-176; 135,1-9.

Kolumna XV. Ps 135,17-21; 136,1-16.

Kolumna XVI. Ps 136,26; 118,1.15.16.8.9.29; 145,1-7.

Kolumna XVII. Ps 145,13-21.

Kolumna XVIII. Ps. 154.

Kolumna XIX. Prośba o wyzwolenie (Plea for Deliverance).

Kolumna XX. Ps 139,8-24; 137,1 .

Kolumna XXI. Ps 137,9; 138,1-8; Syrach 51,13-20.

Kolumna XXII. Syrach 51,30; Apostrofa do Syjonu (Apostrophe to Zion); Ps 93,1-3.

Kolumna XXIII. Ps 141,5-10; 133,1-3; 144,1-7.

17 Por. Sanders, The Psalms Scroll of Qumran Cave 11, 9-14. Plate XVI. 
Kolumna XXIV. Ps 144,$15 ; 155$.

Kolumna XXV. Ps 142,4-8; 143,1-8.

Kolumna XXVI. Ps 149,7-9; 150,1-6; Hymn do Stworzyciela (Hymn to the Creator).

Kolumna XXVII. 2 Księga Samuela 23,7; Kompozycje Dawida (David's Compositions); Ps 140,1-5.

Kolumna XXVIII. Ps $134,1-3 ; 151^{18}$.

Możemy więc zauważyć, iż 11QPs ${ }^{\mathrm{a}}$ zawiera 37 psalmów znanych z Tekstu Masoreckiego, których sekwencja $\mathrm{w}$ wielu miejscach zgadza się z tradycyjnym porządkiem w tekście biblijnym (101-103; 121-132; 135-136; 142-143; 149-150), ale w pozostałych wypadkach teksty odbiegają od układu kanonicznego. Kolejną ważną rzeczą wynikającą z naszej obserwacji jest obecność dziewięciu utworów, których brakuje w Psałterzu Masoreckim. Trzy z nich, a więc psalmy 151, 154, 155, były znane do czasu odkrycia manuskryptu w innych wersjach Psałterza. Psalm 151 do 1961 r. był znany w wersji greckiej (Septuaginta), syryjskiej (Peszitta) i łacińskiej (Vulgata), pozostałe dwa psalmy apokryficzne 154 i 155 funkcjonowały w thumaczeniu syryjskim. Dwa następne teksty: $2 \mathrm{Sm} 23,7$ oraz Syr 51, 30, były dostępne w innych księgach biblijnych. Pozostałe cztery: Prośba o wyzwolenie, Apostrofa do Syjonu, Hymn do Stworzyciela i Kompozycja Dawida, to teksty, które wcześniej nie były znane ${ }^{19}$.

\subsection{Dyskusja nad charakterem $11 Q P s^{a}$}

Publikacja odkrytych manuskryptów wywołała w świecie naukowców wiele sporów nad ich funkcją, datacją czy sposobem rekonstrukcji. Dyskusja nad wieloma wydanymi tekstami powoli nabierała tempa, jednak nad zwojem psalmów rozpoczęła się natychmiast po jego wydaniu. S. Talmon i M. Goshen-Gottstein w wielu artykułach próbowali obalić stanowisko wypracowane przez Sandersa $^{20}$. W opinii Talmona nietradycyjny porządek i interpolacje w tekście dyskwalifikują zwój jako „Psałterz”, który jawi się jako zwyczajny modlitewnik.

18 Por. Sanders, The Psalms Scroll of Qumran Cave 11, 19-49; VanderKam, Manuskrypty, 135-136; VanderKam - Flint, The Meaning of the Dead Sea Scrolls, 122; Nieco inny podział kolumn zaproponował Dahmen. Jego rekonstrukcja zakłada istnienie pierwszej kolumny we fragmentach A, B, C I; fragment C II zawiera drugą kolumnę; płat D przedstawia kolumnę czwartą, dlatego we wspomnianym opracowaniu układ psalmów jest nieco inny niż u Sandersa, Dahmen, Psalmen - und Psalter, 62-100; Flint, The Dead Sea Psalms Scrolls and the Book of Pslams, 159, 190; F. Garcia Martinez - E.J.C Tigchelaar, The Dead Sea Scrolls. Study Edition (Leiden - New York - Köln: Brill 1999) I, 1172-1179.

19 VanderKam, Manuskrypty, 136; VanderKam - Flint, The Meaning of the Dead Sea Scrolls, 122.

20 Por. E. Ulrich, The Dead Sea Scrolls and the Developmental Composition of the Bible (Supplements to Vetus Testamentum 169; Leiden - Boston: Brill 2015) 194. 
Goshen-Gottstein dodał, iż wzmianka o 4050 kompozycjach Dawidowych nie pokazuje, że intencją pracy było stworzenie zwoju o charakterze skrypturystycznym, ale wzmocnienie utworów apokryficznych przypisanych Dawidowi ${ }^{21}$. Spór dotyczący charakteru manuskryptu podzielił znanych naukowców na przeciwników i obrońców statusu biblijnego. I tak teoria zakładająca, iż jest to modlitewnik bądź zwój liturgiczny, ma licznych zwolenników, do których należą: M. Goshen-Gottstein, S. Talmon, P. Skehan, M. Haran, E. Tov ${ }^{22}$. Całość założeń przeciwnych rozumieniu zwoju jako tekstu biblijnego można przedstawić skrótowo w pięciu najważniejszych punktach:

1. Sekwencja psalmów w 11QPs jest inna od tej, którą znamy z Tekstu Masoreckiego.

2. Zwój zawiera dodane psalmy, których nie znajdziemy w Tekście Masoreckim.

3. Manuskrypt jest zwojem liturgicznym. Dla przykładu, w strukturze Psalmu 145 występuje sukcesywnie powtarzana antyfona, jednak w TM tej antyfony nie ma.

4. Tetragram jest zapisany pismem paleo-hebrajskim.

5. Zawarte elementy prozy pomiędzy psalmami świadczą na niekorzyść jego biblijnej funkcji ${ }^{23}$.

Wbrew tym twierdzeniom występują badania zwolenników biblijnego charakteru 11QPs ${ }^{\mathrm{a}}$, wśród których znajdują się: J.A. Sanders, G. Wilson, P. Flint, E. Urlich ${ }^{24}$. Ostatni z nich w swojej monografii w 12. rozdziale zatytułowanym „Nonbiblical scrolls now recognized as scriptural” słusznie podważył wszystkie postawione wyżej zarzuty, wytaczając przeciwko nim silne argumenty skrypturystyczne, jak choćby przykład Psalmu 136, który wchodzi w skład psałterza kanonicznego, mimo że ma regularnie powtarzaną antyfonę ${ }^{25}$. W świetle tej analizy zwój stanowi jeden z możliwych wariantów psałterza, które mogły funkcjonować we wspólnocie z Qumran.

\section{Postać Dawida w Psalmie 151}

Psalm 151 znajduje się na samym końcu zwoju w kolumnie XXVIII. Górna część tej kolumny zawiera trzy wersety Psalmu 134 zapisane w dwóch liniach. Niżej

21 Ulrich, The Dead Sea Scrolls, 194.

22 VanderKam - Flint, The Meaning of the Dead Sea Scrolls, 123.

23 Ulrich, The Dead Sea Scrolls, 195. Wspomniane punkty cytuje i krótko omawia Dahmen w pierwszej części swojej pracy, która stanowi status questionis, Dahmen, Psalmen - und Psalter, 17-18.

24 VanderKam - Flint, The Meaning of the Dead Sea Scrolls, 123.

25 Ulrich, The Dead Sea Scrolls, 195-199. 
widoczna jest cezura, po której następuje kolejny, a zarazem ostatni tekst zwoju - Psalm 151, obejmujący linie od 3. do 14., przy czym, jak zauważają słusznie niektórzy egzegeci, część 3-12 stanowi Psalm 151a ${ }^{26}$, natomiast 13-14 - Psalm $151 b^{27}$; w poniższej części dokonamy podobnego podziału.

\subsection{Tekst hebrajski Psalmu 151a wraz z polskim tłumaczeniem (11QPs ${ }^{\mathrm{a}}$ kolumna XXVIII)}

\begin{tabular}{|c|c|}
\hline cezura & Numer linii \\
\hline הללויה לדויד בן ישי קטן הייתי מן אהי וצעיר מבני אבי וישימני & 3 \\
\hline רועה לצונו ומושל בגדיותיו ידי עשו עוגב ואצבעותי כנור & 4 \\
\hline ואשימה ליהוה כבוד אמרתי אני בנפשי ההרים לוא יעידו & 5 \\
\hline לו והגבעות לוא יגידו עלו העצים את דברי והצואן את מעשי & 6 \\
\hline כי מי יגיד ומי ידבר ומי יספר את מעשי אדון הכול ראה אלוה & 7 \\
\hline הכול הוא שמע והוא האזין שלח נביאו למושחני את שמואל & 8 \\
\hline לגדלני יצאו אחי לקראתו יפי התור ויפי המראה הגבהים בקומתם & 9 \\
\hline היפים בשערם לוא בחר יהוה אלוהים בם וישלח ויקחני & 10 \\
\hline מאחר הצואן וימשחני בשמן הקודש וישימני נגיד לעמו ומושל בבני & 11 \\
\hline בריתו - (28 & 12 \\
\hline
\end{tabular}

\section{Halleluja Dawida, syna Jessego. Byłem najmniejszy spośród moich braci} i najmłodszy z synów mojego ojca. Uczynił mnie

4. pasterzem dla swych owiec i władcą (dozorcą) nad jego trzodą. Moje ręce uczyniły instrument i moje palce cytrę.

5. I oddawałem Bogu chwałę. Powiedziałem w swojej duszy: Góry nie mogą dać o Nim świadectwa,

6. a pagórki nie zaświadczą o nim. Drzewa wypielęgnowały moje słowa a trzoda moje czyny.

26 Sanders w opracowaniu krytycznym zwoju na samym końcu zamieścił facsimile tekstu, na których widać wyraźnie cezurę oddzielającą Psalm 134 od 151a. Między linią 12. a 13. kolumny XXVIII również widoczny jest odstęp, jednak nieco mniejszy, Sanders, The Psalms Scroll of Qumran Cave 11, Plate XVII.

27 Por. Sanders, The Psalms Scroll of Qumran Cave 11, 49-64; A. Tronina, „Psalm 151 - Poetycki midrasz do dziejów Dawida”, Roczniki Teologiczne 43/1 (1996) 85; M. Segal, „The Literary Developement of Psalm 151: A New Look at the Septuagint Version”, Textus 21 (2002) 139.

28 Por. Sanders, The Psalms Scroll of Qumran Cave 11, 54-55; Segal, „The Literary Developement of Psalm 151: A New Look at the Septuagint Version", 140-141; Dahmen, Psalmen-und Psalter, 98; A. Farutin, „Tekst Psalmu 151 w rękopisie 11Q5 z Qumran i w Septuagincie. Problem ustalenia pierwotnej redakcji”, Collectanea Theologica 85/1 (2015) 70-71. 
7. Kto ogłosi, kto opowie i kto zliczy dzieła Pana? Bóg wszystko widzi,

8. wszystko słyszy i On zwraca uwagę. Posłał swego proroka, aby mnie namaścił Samuela,

9. aby uczynił mnie wielkim. Moi bracia wyszli mu naprzeciw, pięknej budowy (postaci) i pięknego wyglądu. Choć byli wysokiego wzrostu

10. i mieli piękne włosy, nie wybrał Pan Bóg żadnego z nich. Ale posłał i zabrał mnie

11. spośród trzody i namaścił mnie świętym olejem i ustanowił mnie księciem dla swego ludu i rządcą nad synami

12. Jego przymierza ${ }^{29}$.

Powyższy utwór należy do grupy tekstów pseudoepigraficznych ${ }^{30}$ i uznawany jest jako poetycki midrasz do 1 Sm 16,1-13. Biblijny tekst ukazuje moment wyboru najmłodszego spośród synów Jessego na króla w Izraelu. Sanders zauważa, iż centralnym punktem w opowiadaniu biblijnym jest stwierdzenie: „Bóg patrzy na serce" 1 Sm 16,7. Wyrażenie to nic nie mówi o tym, co Pan Bóg dostrzegł w sercu młodego Dawida, stąd możemy uznać, iż intencją autora midraszu było uzupełnienie tej luki. Nawet jeśli Dawid jest najmniej znaczący w domu swojego ojca, to jednakże ze względu na czyste serce zostaje wywyższony przez Boga ${ }^{31}$.

\subsection{Analiza słownictwa}

Linia trzecia w kolumnie XXVIII otwiera nowy tekst - Psalm 151a. Pierwsze cztery słowa הללויה לדויד בן ישי stanowią wprowadzenie do całości utworu, uznawane przez wielu badaczy za tytuł do całości kompozycji. W tym krótkim zdaniu werbalnym autor psalmu definiuje pochodzenie Dawida jako syna Jessego: ישי בן Rzeczownik - ,syn” (status constructus 1. poj.) - ściśle określa relację

29 Por. Sanders, The Psalms Scroll of Qumran Cave 11, 54-56; Tronina, „Psalm 151 - Poetycki midrasz do dziejów Dawida”, 85-86; Witt, „David, the «Ruler of the Sons of His Covenant»”, 84-85; A. Kowalski, „Psalmy 151-155 (syryjskie psalmy apokryficzne 1-5)”, Warszawskie Studia Teologiczne VII (1994) 22; J. Bjornar Storfjell, ,The Chiastic Structure of Psalm 151”, Andrews University Seminary Studies 25 (1987) 100; Farutin, „Tekst Psalmu 151 w rękopisie $11 Q 5$ z Qumran i w Septuagincie. Problem ustalenia pierwotnej redakcji”, 70-71; P. Muchowski, Rękopisy znad Morza Martwego: Qumran - Wadi Murabbaat - Masada - Nachal Chewer (Biblioteka Zwojów: Tło Nowego Testamentu; Kraków: The Enigma Press 2000) 442.

$30 \mathrm{Na}$ temat tekstów pseudoepigraficznych warto sięgnąć do pozycji P. Flinta, w której autor wyjaśnia definicję teksów pseudoepigraficznych i ich kategorie, P. Flint, The Bible at Qumran. Text, Shape and Interpretation (Grand Rapids - Michigan - Cambridge: W.B. Eerdmans 2001) 88-89.

31 Por. Sanders, The Psalms Scroll of Qumran Cave 11, 56; Segal, „The Literary Developement of Psalm 151”, 147; Tronina, „Psalm 151 - Poetycki midrasz do dziejów Dawida”, 85. 
do drugiego członu, dlatego rzeczownik Jesse w świetle analizy syntaktycznej może być uznany przez nas jako genetivus subiectivus relationis ${ }^{32}$.

W Tekście Masoreckim rzeczownik בן używany jest przez hagiografów w różnych kontekstach ${ }^{33}$, w Psalmie 151a nie ma najmniejszej wątpliwości, iż chodzi o relację pomiędzy ojcem i synem.

Od piątego słowa w linii trzeciej rozpoczyna się właściwa treść Psalmu 151a, co sugeruje przejście podmiotu, będącego jednocześnie narratorem, do 1. os. 1. poj., wyrażonej przez czasownik היה (,być”) w formie perfectum koniugacji Qal. Z punktu widzenia czytelnika tekst jawi się jako autobiografia Dawida opowiadającego o swojej przeszłości. Sam początek psalmu eksponuje dwa קטן i צעיר: synonimiczne przymiotniki odnoszące się do Dawida

Przymiotnik קטן swoje pole semantyczne ogranicza do trzech możliwości tłumaczenia. Pierwszą jest: „mały”, „krótki” (Rdz 1,16; $1 \mathrm{Krl}$ 3,7; $2 \mathrm{Krl}$ 5,14), „nieznaczący”, „mało ważny” (Wj 18,22.26), ,pokorny, uniżony” (Jr 49,15), „słaby” (Am 7,2), przy użyciu z partykułą מן po której następuje infinitivus constructus, przyjmuje znaczenie „za mało” (1 Krl 8,64). Kolejna możliwość tłumaczenia odnosi się do wieku. Autorzy biblijni, mając na uwadze to znaczenie, niejednokrotnie dokonują stopniowania przymiotnika w odniesieniu do innych osób: „młodszy, najmłodszy” (Rdz 42,13.15.20.32.34; 44,2.12.23.26). Trzecia opcja translacji ma miejsce wtedy, gdy obok słowa קטן występuje antonim גדל „wielki, duży”, wtedy taka konfiguracja wyraża pewną całość w sensie pozytywnym: „od najmniejszego do największego” (Rdz 9,11; $1 \mathrm{Sm} 5,9 ; 30,2.19)$, lub negatywnym: ,ani z małym, ani z dużym, z nikim” (1 Krl 22,31; 2 Krn 18,30) ${ }^{34}$.

Przymiotnik ten użyty jest w psalmie z partykułą מן stojąca bezpośrednio przed rzeczownikiem w liczbie mnogiej („bracia”) opatrzonym sufiksem 1. os. 1. poj.

32 Por. B.K. Waltke - M. O'Connor, An Introduction to Biblical Hebrew Syntax (Winiona Lake: Eisenbrauns 1990) 145.

33 Wspomniany rzeczownik w zależności od kontekstu przyjmuje różne znaczenie. I tak określa relację rodzinną między ojcem a synem, dziadkiem a wnukiem Rdz 32, 1 יישכם לבן בבקר וינשק לבניו ולבנותיו, odnosi się do ukazania pewnej indywidualności w większej grupie osób Ez 2,1. Dalej rzeczownik ten określa naród, klan, ruch, stowarzyszenie Ps 149, 2 בן ציון; Ne 12,23; J1 4,6; Ne 13,15; Ps 137,7; Rdz 19,38; Ez 23,15; J1 4,6. W 1 Sm 10,5 status constructus לבן נביאיח oznacza przynależność do grupy prorockiej, paralelnie tę konstrukcję, tylko w liczbie mnogiej, możemy spotkać w Am 7,14. Przynależność do grupy możemy znaleźć u proroka Izajasza, który używa omawianego rzeczownika w satus constructus do określenia człowieka przynależącego do nurtu ludzi uczonych, mędrców: בן־חכמים. W Lb 17,25 znajdujemy określenie ludzi

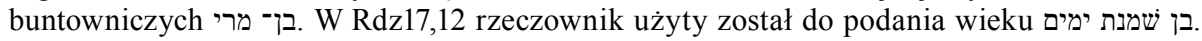
Omawiany rzeczownik wskazuje także na cechy lub wiek; niejednokrotnie charakteryzuje młode zwierzę . L. Koehler - W. Baumgartner - J.J. Stamm, The Hebrew and Aramaic Lexicon of the Old Testament (Leiden - New York - Koln: Brill 1994) 137-138. Analizę, etymologię, znaczenie teologiczne tego rzeczownika możemy znaleźć w J. Bergman - J. Ringgren - H. Haag, „בן, ThWAT I, 668-682.

34 HALOT, 1092-1093. 
Taka konstrukcja zakłada w tym wypadku porównanie osoby wyrażonej przez przymiotnik (Dawida) z grupą określoną przez rzeczownik, dlatego w świetle analizy syntaktycznej i treści $1 \mathrm{Sm} 16$ omawiany przymiotnik powinien być rozumiany jako stopień najwyższy „,najmłodszy, najmniej znaczący” ${ }^{35}$, mimo braku rodzajnika określonego przy przymiotniku, który w klasycznych przypadkach nasuwa w tekście takie tłumaczenie. Co ciekawe, omawiany przymiotnik jest częścią zdania werbalnego, którego budowa jest nieco inna od klasycznego szyku takiego zdania w języku hebrajskim. Zwykle na pierwszym miejscu powinien znajdować się czasownik w formie osobowej będący orzeczeniem, natomiast na drugim - podmiot. W tym przypadku przed czasownikiem $\mathrm{w}$ formie osobowej znajduje się przymiotnik. Taka konfiguracja nie jest ewenementem, podobny przypadek znajdujemy w Hi 1,1 איש היה בארץ־עוץ איוב שמו ש̇ył pewien człowiek w ziemi Uz, a jego imię Hiob”. Stojący więc przed czasownikiem היה przymiotnik podkreśla sposób egzystencji podmiotu, a więc w świetle tej analizy możemy stwierdzić, że funkcja znajdującego się tu przymiotnika nie sprowadza się tylko do wyrażenia fizycznego wyglądu, małego wzrostu, ale podkreśla sposób życia Dawida jako najmniej znaczącego, uniżonego w swoim istnieniu.

W tej samej linii znajdujemy drugi przymiotnik צעיר posiadający zbliżone znaczenie do pierwszego, które możemy ograniczyć do czterech aspektów. Pierwszym jest użycie tego przymiotnika wtedy, gdy autor biblijny chciał dokonać jego stopniowania w znaczeniu „mały, mało”, odnosząc się do osoby, rzeczy, stanu (1 Sm 9,21; Iz 60,22; Mi 5,1). Drugi aspekt ma na celu stopniowanie, jak wyżej, ale w znaczeniu ,młodszy, najmłodszy” (Rdz 19,31.34.35.38; 25,23;29,26; 43,33; 48,14; Joz 6,26; $1 \mathrm{Krl} 16,34)$. Trzecie znaczenie sprowadza się do „kogoś lub czegoś małego” w sensie fizycznym (Jr 49,20) i przenośnym (Ps 119,141). Ostatnie jest stosowane do określenia służącego, chłopca $(\mathrm{Jr} 14,3)^{36}$. W przypadku psalmu mamy do czynienia z superlativem przymiotnika „młody”, wynikającym ze stojącej bezpośrednio za nim partykuły מן ściśle powiązanej ze status constructus מבני אבי. We wspomnianym ciągu dopełniaczowym możemy znaleźć z syntaktycznego punktu widzenia genetivus adiectivalis attributivus. Tutaj genetivus jest opatrzony sufiksem 1. os. 1. poj., który odnosi się do całego wyrażenia dopełniaczowego.

Niektórzy egzegeci przez użycie tych dwóch przymiotników widzą bez-

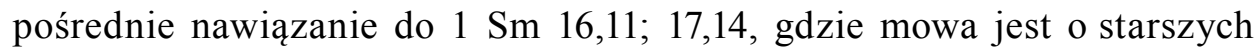
braciach Dawida, natomiast konfiguracja, w której najpierw znajduje się przymiotnik צטן, a za nim צעיר jest, według nich, wpływem tekstu Iz 60,22

35 Waltke - O'Connor, An Introduction, 214.

36 HALOT, 1041. 
z najmniejszego stanie się tysiącem i z najmniej znaczącego ludem licznym" ${ }^{37}$.

Ostatnia syntagma וישימנ w pierwszej linii rozpoczyna nowe zdanie. Z morfologicznego punktu widzenia jest to czasownik poprzedzony waw consecutivum $\mathrm{w}$ koniugacji Qal w formie imperfectum 3. os. 1. poj. rodz. m. od rdzenia שים z przyrostkiem dopełnienia bliższego (1. os. 1. poj.), dodanego do tematu czasownika. Tak opisaną formę musimy przetłumaczyć „uczynił mnie”, gdzie podmiotem jest Jesse, co podpowiada zdanie poprzednie, natomiast dopełnieniem jest Dawid ${ }^{38}$, spełniający dwie funkcje określone przez participia $\mathrm{w}$ dalszej części linii רועה לצונו ומושל בגדיותיו. Na dowód, iż mamy tu do czynienia z dwoma imiesłowami czynnymi, należy wskazać obecność w obu rdzeniach spółgłoski ı jako mater lectionis dla samogłoski holem, charakterystycznej dla particiupim aktywnego w koniugacji Qal.

Pierwsze participium pochodzi od czasownika רעה rozumianego w znaczeniu przechodnim: „karmić, paść, prowadzić na pastwisko, ochraniać stado jako pasterz oraz metaforycznie ochraniać ludzi, być dla nich pasterzem”. W znaczeniu rzeczownikowym rdzeń charakteryzuje pasterza, tego, który jest za coś odpowiedzialny, tytuł królewski, człowieka przeznaczonego i wybranego przez Boga do sprawowania władzy (Iz 44,28) ${ }^{39}$. W przypadku omawianego tekstu, w wyrażeniu רועה לצונו participium możemy tłumaczyć w dwojaki sposób. Biorąc pod uwagę imiesłów w znaczeniu czasownikowym, należy oddać tekst w sposób opisowy, a więc Jesse ustanowił Dawida „pasącym jego trzodę”. $\mathrm{Z}$ drugiej strony, o wiele lepszym wyjściem jest interpretacja tego rdzenia jako participium urzeczownikowionego ${ }^{40}$ - Dawid został ustanowiony przez ojca „pasterzem”.

Drugi imiesłów מושל od strony morfologicznej, podobnie jak wcześniejszy, jest w rodzaju męskim 1. poj. w koniugacji Qal. Pochodzi on od czasownika rządzić, władać, uczynić kogoś władcą, dominować” i, identycznie jak wyżej, może być rozumiany w tekście dwojako: byłem „rządzącym” nad jego (Jessego) trzodą lub jako participium urzeczownikowione, będące lepszą opcją od pierwszej: byłem ,władcą" nad jego stadem. Omawiany imiesłów łączy się w tekście z rzeczownikiem ${ }^{41}$ גדיות, który morfologicznie znajduje się w liczbie mnogiej rodzaju żeńskiego opatrzony sufiksem zaimkowym 3. os. 1. poj. na końcu i przyimkiem ב na początku, co z syntaktycznego punktu widzenia wymusza tłumaczenie ,ponad, nad trzodą”. Podobne użycie tego przyimka, który odnosi

37 Segal, „The Literary Developement of Psalm 151”, 146.

38 Reymond, New idioms within Old, 55-56.

39 HALOT, 1258-1261.

40 Waltke - O'Connor, An Introduction, 614-615.

41 Takiej formy nie znajdziemy w Tekście Masoreckim. 
się do uprzednio użytego czasownika משל משל, możemy znaleźć w Rdz 3,16, gdzie jest mowa o panowaniu mężczyzny nad kobietą

Drugą część linii 4. stanowi nowe zdanie ידי עשו עוגב ואצבעותי כנור. Dawid przedstawia siebie jako tego, który oddaje się pracy nad wytworzeniem instrumentów. Czynność tę wyraża czasownik עשיש, oznaczający, ,wytworzyć coś, zrobić coś, stworzyć, przygotować, dać jakiś efekt" "43; za pomocą własnych rąk i palców tworzy flet ${ }^{44}$ oraz cytrę ${ }^{45}$. Taka konfiguracja, w której pojawiają się wspomniane instrumenty jednocześnie, nie została wzięta znikąd, ale nawiązuje do Tekstu Masoreckiego: Rdz 4,21; Hi 21,12; 30,31 ${ }^{46}$. Księgi kanoniczne w kilku miejscach mówią o ,instrumentach Dawida”: Ne 12,36; 1 Krn 23,5; 2 Krn 29,26-27; w przywołanych fragmentach jest to podyktowane tradycją dzieła kronikarskiego (włączając w to Księgę Nehemiasza, bez względu na kwestię autorstwa), która podkreślała fakt ustanowienia przez Dawida funkcji śpiewaków i muzyków skupionych w Świątyni Jerozolimskiej (1 Krn 6,16; 16,4-7) ${ }^{47}$. Również w literaturze prorockiej możemy znaleźć ślad przypisywania Dawidowi zdolności do konstruowania instrumentów muzycznych, o czym wspomina prorok Amos $(6,5)$. Informacja o talencie muzycznym Dawida ma swoje potwierdzenie w $1 \mathrm{Sm} \mathrm{16,15-23.}$ Deuteronomista relacjonuje wydarzenie z życia młodego Dawida oddającego się grze na cytrze dla uśmierzenia cierpień króla Saula. Tekst księgi kanonicznej nie mówi kiedy, gdzie czy w jakim celu Dawid posiadł umiejętność gry na wspomnianym instrumencie, stąd na pierwszy rzut oka wydaje się, iż intencją autora midraszu było rozwiązanie tej kwestii, jednak w dalszym kontekście sam tekst daje odpowiedź, objaśnia samego siebie. Wytworzenie instrumentów i gra na nich ma, według psalmu, jeden cel: oddanie chwały Bogu ${ }^{48}$, o czym mówi początek 5. linii w omawianej kolumnie rozpoczynającej się słowami ואשימה כבוד ליהוה, co dosłownie możemy przetłumaczyć: „uczyniłem dla Boga chwałę". Mamy tu do czynienia z klasycznym zdaniem werbalnym, gdzie na pierwszym miejscu stoi czasownik w formie osobowej, wyrażający podmiot (1. os. 1. poj. w koniugacji Qal) połączony z waw consecutivum. Z punktu widzenia składni sam czasownik może być rozumiany jako tak zwany pseudocohortativus"

42 HALOT, 647-648.

43 HALOT, 889-893.

44 HALOT, 795.

45 HALOT, 485.

46 Por. Sanders, The Psalms Scroll of Qumran Cave 11, 57.

47 Por. R. Rendtorff, „The Psalms of David: David in the Psalms”, The Book of Psalms. Composition and Reception (red. P.W. Flint - P.D. Miller) (Leiden - Boston: Brill 2005) 54.

48 Por. D. Dimant, „David's Youth in the Qumran Contekst (11QPsa 28, 3-12)”, Prayer and Poetry in the Dead Sea Scrolls and Related Literature. Essays in Honor Eileen Schuller on the Occasion of Her 65th Birthday (red. J. Penner - K.M. Penner - C. Wassen) (Leiden - Boston: Brill 2012) 104-105. 
połączony z waw consecutivum ${ }^{49}$, który jak zauważa Reymond, jest dość powszechnie stosowany przez autorów manuskryptów z Qumran ${ }^{50}$. Obecność takiej formy w tym miejscu (linia 5.) ma potrójną funkcję: jest konsekwencją zdania poprzedzającego; sprawia, że tekst jest treściowo spójny, płynny; wprowadza czytelnika w dalszą narrację.

Po adnotacji, iż Dawid oddaje chwałę Bogu, powinniśmy spodziewać się informacji, w jaki sposób podmiot tę czynność wyraża, tak jednak się nie dzieje, gdyż autor psalmu wprowadza kolejne zdanie werbalne: אמתרי אני בנפשי ,powiedziałem w swojej duszy", chcąc pokazać sferę, w której dokonuje się ten akt.

Czasownik אמר - ,mówić” użyty w formie perfectum 1. os. 1. poj. w koniugacji Qal i połączony z zaimkiem osobowym 1. os. 1. poj. rodz. m. אני wyraża tutaj pewną emfazę: „to ja powiedziałem”. Taka konstrukcja może wskazywać na to, iż Dawid jest jedynym autorem chwały oddawanej Bogu, jest to jego osobiste działanie skierowane w stronę Jahwe.

Z naszego punktu widzenia ważny jest w zdaniu hebrajski rzeczownik נפשש, opatrzony na początku partykułą $ב$ i sufiksem osobowym 1. os. 1. poj. na końcu. Sam rzeczownik w Tekście Masoreckim przyjmuje różne znaczenia: „,gardło” (Iz 29,8), „szyja” (Ps 69,2; 124,4), „oddech” (Hb 41,13), „istota żywa” (Rdz 1,20.24; Kpł 11,10), ,człowiek” (Kpł 24,17), ,niewolnik, życie” (Rdz 19,17; Prz 7,23), „dusza” (Jr 44,14), ,martwa dusza, umarły”, funkcję zaimka zwrotnego. Biorąc pod uwagę kontekst psalmu i formę rzeczownika, możemy uwzględnić trzy możliwości: „dusza, gardło” lub zaimek zwrotny. Jeśli przyjmiemy znaczenie „gardło”, wtedy znajdującą się na samym początku partykułę ב powinniśmy rozumieć jako bet instrumentalis, a więc tłumaczenie powinno wyglądać: ,powiedziałem przez swoje gardło, powiedziałem za pomocą mojego gardła”. Gdy uznamy drugą możliwość, to wspomniana partykuła powinna być pojmowana jako bet localis, co przyczynia się do zmiany thumaczenia: „powiedziałem w mojej duszy”. Wtedy tekst wskazuje nam konkretną sferę, miejsce, w którym odbywa się osobisty akt uwielbienia Boga przez Dawida.

W Tekście Masoreckim konstrukcja אמרתי אני בנפשי nie pojawia się ani razu, zamiast niej autorzy biblijni stosują i powiedziałem w swym sercu" (Koh 2,1.15; 3.17.18). To pokazuje, iż miejscem medytacji, rozważania człowieka jest w świetle antropologii biblijnej nie dusza, lecz serce. Tak więc

49 „In about ninety cases the waw-relative occurs with the pseudo-cohortative, principally in the parts of Daniel, Ezra, and Nehemiah where the narrative is in the first person, and rarely elsewhere (34.5). This is not necessarily a late feature of the language: it is not used by the postexilic writer of Chronicles, but it is used by the earlier Deuteronomist (cf. $1 \mathrm{Chr}$ 17:8 with 2 Sam 7:9). Moreover, it is not found in Zechariah 1-8 or Esther, both of which are post-exilic", Waltke - O'Connor, An Introduction, 544, 576-577.

50 Reymond, New idioms within Old, 56.

51 HALOT, 6283-6284. 
należałoby odrzucić drugie znaczenie, ale według opinii Hurvitza, wyrażenie jest charakterystyczne dla chrześcijańskiego aramejskiego ${ }^{52}$, który patrząc na datację naszego zwoju, jest mu czasowo bardzo bliski, natomiast w opinii Sandersa rzeczownik נפש funkcjonuje w psalmie jako późniejszy synonim rzeczownika לב ${ }^{53}$.

Ostatnim wariantem jest interpretacja tego rzeczownika jako zaimka zwrotnego, co sugerowałoby thumaczenie ,powiedziałem w sobie samym, sobie samemu”. Takie objaśnienie jest do przyjęcia, ale jego przesłanie jest znacznie uboższe od omówionej wyżej drugiej możliwości, będącej w tym wypadku najlepszą opcją ze względu na kontekst następujący bezpośrednio po niej.

Od połowy linii 5. aż do pierwszej części linii 8. rozpoczyna się druga część psalmu, będąca monologiem Dawida, w którym wyraża on wspomnianą wyżej chwałę względem Boga ${ }^{54}$. Druga połowa linii 8. kończy „modlitwę Dawida” i rozpoczyna nową sekcję w psalmie, mówiącą o jego namaszczeniu i wyborze na władcę. Zmienia się w tym momencie podmiot działający. O ile w pierwszej części tym, który ustanawiał Dawida pasterzem i dozorcą trzody, był jego ojciec Jesse, o tyle w tym segmencie wszelkie zadania zleca Bóg.

W zdaniu שלה ניאו למושחני את שמואל לגדלני zmianę podmiotu działającego pokazuje czasownik שלח - ,posyłać” (perfectum 3. os. 1. poj. rodz. m. w koniugacji Qal), którego forma podyktowana jest w tekście przez kontekst poprzedzający. Mamy tu do czynienia ze zdaniem werbalnym, w którym występuje ciąg apozycyjny rzeczowników נביאו -,jego, swego proroka” - i שת - אמואל -,Samuela”. Prorok staje się wykonawcą planu Bożego co do Dawida, wyrażonego przez użyty dwukrotnie hebrajski infinitivus constructus למושחני - ,aby mnie namaścił” i לגדלני - ,aby mnie wywyższył”. Od strony syntaktycznej infinitivus constructus został zastosowany przez autora dla wyjaśnienia czasownika znajdującego się na początku i wyrażenia celu misji Samuela.

Realizacja zapowiedzi o namaszczeniu i wywyższeniu Dawida nie następuje od razu, całość linii 9. z wyjątkiem pierwszego słowa i ponad połowa 10. ukazują nam braci Dawida. Tekst $1 \mathrm{Sm} \mathrm{16,6-10} \mathrm{wspomina} \mathrm{o} \mathrm{siedmiu} \mathrm{synach} \mathrm{Jessego,} \mathrm{ale}$ informacja o wyglądzie fizycznym pojawia się tylko przy Eliabie (Sm 16,6-7). Psalm 151a rozbudowuje charakterystykę braci Dawida jako mężczyzn o pięknej budowie, wyglądzie, włosach i wysokim wzroście. Mimo pozytywnych

52 Dimant, „David's Youth in the Qumran Contekst (11QPsa 28, 3-12)”, 105.

53 Sanders, The Psalms Scroll of Qumran Cave 11, 57.

54 Tą częścią nie będziemy zajmować się w artykule, gdyż jej interpretacja wykracza poza ramy tematu. Warto jednak nadmienić, iż fragment mówiący o modlitwie Dawida jest mocno dyskutowany przez naukowców w kwestii jego tłumaczenia. Tę dyskusję ożywia opuszczenie wspomnianego fragmentu w Septuagincie i paleografia, o czym wspomnieliśmy wyżej, szczególnie trudność z właściwym odczytaniem spółgłosek waw i yod, które w manuskrypcie mają nieregularną pisownię. 
aspektów budowy fizycznej psalmista konkluduje: לוא בחר יהוה אלוהים בם wybrał Pan Bóg żadnego z nich". Tak skonstruowany wniosek autora wydaje się mocno osadzony na treści 1 Sm 16,7 יהוה יראה ללבב - Bóg patrzy na serce”, oraz wspomnianej wyżej osobistej modlitwie Dawida (linie 5-8). Od końca linii 10. aż do 12. włącznie autor psalmu przechodzi do realizacji Bożego planu względem Dawida, który zostaje zabrany od trzody i namaszczony świętym olejem.

Wyrażenie וימשחני (waw consecutivium + imperfectum koniugacji Qal + przyrostek dopełnienia bliższego 1. os. 1. poj.) pochodzi od czasownika משח - „,namaszczać, rozmazywać, być namaszczonym” 55 i łączy się ze status constructus משמן הקודש ,olejem świętym”. W tym wypadku mamy do czynienia z genetivem adiectivalis attributivus, opisującym cechy rzeczownika wyrażonego w status constructus. Według treści psalmu Samuel dokonuje namaszczenia Dawida za pomocą świętego oleju. Możemy przypuszczać, że ta informacja została umieszczona w tekście pod wpływem wcześniej zredagowanego Psalmu $89^{56}$. Jest to utwór zaliczany do grupy psalmów mesjańskich ${ }^{57}$, który w 21 . wersecie zawiera informację o namaszczeniu Dawida za pomocą świętego oleju: znalazłem Dawida mojego sługę, moim olejem świętym go namaściłem".

Namaszczenie uprawnia Dawida do sprawowania najważniejszych funkcji w Izraelu, które wymienia autor w 11. i 12. linii: נגיד לעמו ומושל בבני בריתו -księciem dla jego ludu i rządcą nad synami Jego przymierza”. Pierwszą z dwóch funkcji określa rdzeń נגיד - ,książę, władca”, rozumiany w dwojaki sposób. Z jednej strony, możemy rozumieć ten rzeczownik jako participium pasywne od czasownik נג i jako tzw. passivum divinum, oznaczające człowieka ,wskazanego przez Boga, wybranego przez Boga". Z drugiej strony, możemy zinterpretować ten rdzeń jako formę czasownikową koniugacji Hifil, która oznaczałaby ,proklamację, głoszenie” i łączyłaby funkcję Dawida z jego psalmami, w których proklamuje i głosi łaskawość i dobroć Boga $^{58}$. W kontekście całego utworu opcja pierwsza narzuca się sama ze względu na mnogość informacji w psalmie, który podkreśla, szczególnie w drugiej i trzeciej części, silne działanie Boga wywyższającego Dawida przez proroka Samuela. Słowo נגיד w linii 11. łączy się bezpośrednio z rzeczownikiem עם - ,lud”, opatrzonym sufiksem osobowym 3. os. 1. poj. rodz. m. i partykułą ל, znajdującą się na samym początku, która wyraża dativus adresata, „ludowi, który należy do Boga - Izraelowi”.

55 HALOT, 643-644.

56 Farutin, „Tekst psalmu 151 w rękopisie 11Q5 z Qumran i w Septuagincie. Problem ustalenia pierwotnej redakcji”, 90; Tronina, „Psalm 151 - Poetycki midrasz do dziejów Dawida”, 86.

57 Por. F.L. Hossfeld - E. Zenger, Psalmen 51-100 (Herders Theologischer Kommentar zum Alten Testament; Freiburg - Basel - Wien: Herder 2000) 577-601.

58 Por. A. Zawadzki, „Nowe tłumaczenie i interpretacja Iz 55,3-5. Studium egzegetyczno-historyczne", Biblical Annals 7/1 (2017) 75. 
Drugą funkcję uwidacznia participium aktywne מושל posiadające identyczną formę i znaczenie jak w linii 4. z pewną różnicą, która wynika z jej nadania. W linii 4. participium odnosiło się do władzy nad trzodą należącą do Jessego, który był jednocześnie podmiotem nadającym tę funkcję Dawidowi. W 11. linii znaczenie tego participium urzeczownikowionego nie zmienia się, dalej mowa jest o sprawowaniu władzy przez Dawida, zmianie ulega podmiot nadający tę funkcję i sfera realizacji rządów; tym, który przekazuje władzę, jest Bóg, a sfera jej sprawowania nie dotyczy już zwierząt, ale ludzi synów Jego przymierza”.

\subsection{Struktura Psalmu 151a}

Analizując utwór pod kątem retoryki, możemy zauważyć w Psalmie 151a strukturę nazywaną chiazmem ${ }^{60}$. J.B. Storfjell podzielił psalm na 10 wersów; 1-5 tworzą pierwszą strofę, 6-10 - drugą. Według jego założeń chiazm wygląda następująco:

\section{Strofa pierwsza}

\begin{tabular}{|l|l|l|}
\hline & Byłem najmniejszy spośród moich braci & $\mathrm{abc}$ \\
i najmłodszy z synów mojego ojca. & $\mathrm{ac}$ \\
Uczynił mnie pasterzem dla swych owiec & $\mathrm{abc}$ \\
i władcą (dozorcą) nad jego trzodą. & $\mathrm{bc}$ \\
\hline & Moje ręce uczyniły instrument & $\mathrm{abc}$ \\
i moje palce cytrę. & $\mathrm{ac}$ \\
I oddawałem Bogu chwałę. & xyz \\
\hline & Powiedziałem w swojej duszy: & $\mathrm{xyz}$ \\
Góry nie mogą dać o Nim świadectwa, & $\mathrm{abc}$ \\
a pagórki nie zaświadczą o nim. & $\mathrm{ab}$ \\
\hline & Drzewa wypielęgnowały moje słowa, & $\mathrm{abc}$ \\
a trzoda moje czyny. & $\mathrm{bc}$ \\
\hline Kto ogłosi, & $\mathrm{ab}$ \\
kto opowie & $\mathrm{ab}$ \\
i kto zliczy dzieła Pana? & $\mathrm{abc}$ \\
\hline
\end{tabular}

59 Przywołana fraza (synowie jego przymierza) nie funkcjonuje w Tekście Masoreckim, jej obecność wykazują tylko manuskrypty z Qumran: 1QM, 4Q284, 4Q503, 4Q501, 11Q5. Próbę rozwiązania problemu znaczenia tego wyrażenia podjął A.C Witt w jednym ze swoich artykułów, który daje częściową odpowiedź na pytanie, jak rozumieć wspomnianą frazę, Witt, „David, the «Ruler of the Sons of His Covenant»”, 87-97.

$60 \mathrm{Na}$ temat chiazmu i innych figur retorycznych w poetyce hebrajskiej W.G.E. Watson, Classical Hebrew Poetry. A Guide to its Techniques (Journal for the Study of the Old Testament Supplement Series 26; Sheffield: JSOT Press 1986) 14, 201-207. 


\section{Strofa druga}

\begin{tabular}{|l|l|l|}
\hline $\begin{array}{l}\text { Bóg wszystko widzi, } \\
\text { wszystko słyszy } \\
\text { i On zwraca uwagę. }\end{array}$ & $\begin{array}{l}\mathrm{abc} \\
\mathrm{abc} \\
\mathrm{ac}\end{array}$ \\
\hline $\begin{array}{l}\text { Posłał swego proroka, aby mnie namaścił, } \\
\text { Samuela, aby uczynił mnie wielkim. }\end{array}$ & $\begin{array}{l}\mathrm{abc} \\
\mathrm{bc}\end{array}$ \\
\hline $\begin{array}{l}\text { Moi bracia wyszli mu naprzeciw, } \\
\text { pięknej budowy (postaci) } \\
\text { i pięknego wyglądu. }\end{array}$ & $\begin{array}{l}\mathrm{xyz} \\
\mathrm{ab}\end{array}$ \\
$\begin{array}{l}\text { Choć byli wysokiego wzrostu } \\
\text { i mieli piękne włosy, } \\
\text { nie wybrał Pan Bóg żadnego z nich. }\end{array}$ & $\begin{array}{l}\mathrm{ab} \\
\mathrm{ab}\end{array}$ \\
\hline $\begin{array}{l}\text { Ale posłał i zabrał mnie spośród trzody, } \\
\text { i namaścił mnie świętym olejem, } \\
\text { i ustanowił mnie księciem dla swego ludu } \\
\text { i rządcą nad synami przymierza. }\end{array}$ & $\mathrm{xyz}$ \\
\hline
\end{tabular}

W wersecie 1. zauważalne są dwa bikolony, gdzie drugi jest progresją myśli pierwszego, natomiast oba zestawione razem tworzą paralelizm syntetyczny. Wers 2. to trikolon obejmujący temat instrumentów, dzięki którym możliwe jest oddanie chwały Bogu. Trikolon 3. rozpoczyna kolejny wers frazą: „powiedziałem w swojej duszy"; tekst ten nie tyle wprowadza w to, co nastąpi dalej, ile konkluduje to, co go poprzedzało. Bikolon 4. jest paralelny w przekazie treści do trikolonu poprzedniego, szczególnie kolonu 2. i 3. Wraz z trikolonem 5. kończy się pierwsza część psalmu ${ }^{62}$. W tym miejscu musimy postawić pytanie: w jaki sposób funkcjonuje 6. trikolon, jak należy rozumieć jego miejsce i funkcję w tekście? W słusznej opinii Sandersa część 5. i 6. tworzą nierozerwalną całość w kompozycji, gdzie wers 5. stawia pytania, natomiast 6 . jest odpowiedzią ${ }^{63}$. Według Storfjella trikolon 6. stanowi jedność treściową połączoną z bikolonem 7., w którym możemy zauważyć paralelizm synonimiczny. Jest to wniosek zbyt daleko idący z powodu różnicy treściowej między wersetami 6. i 7., propozycja Sandersa zaś jest bardziej zasadna ze względu na logiczną strukturę tekstu.

61 Por. J.B. Storfjell, „The Chiastic Structure of Psalm 151”, Andrews University Seminary Studies 25/1 (1987) 100.

62 Storfjell, „The Chiastic Structure of Psalm 151”, 99-101.

63 Sanders w analizie i tłumaczeniu Psalmu 151 umieścił te dwa wersy w jednym: „For who can proclaim and who can bespeak and who can recount the deeds of the Lord? Everything has God seen, everything has he heard and he has heeded", Sanders, The Psalms Scroll of Qumran Cave 11, 56. 
Bikolon 7. eksponuje temat działania Boga w życiu Dawida. Tę interwencję wyraża w pierwszym kolonie rdzeń שלה, będący tutaj czasownikiem głównym. Co więcej, wers 7. mocno akcentuje postać Samuela, o którym tekst grecki zawarty w Septuagincie wspomina bardzo lapidarnie ,posłał swego posłańca” bez podania jego imienia (co czyni wersja ze zwoju) i sprecyzowania jego dalszej misji. Trikolon 8. i 9. to wewnętrzny chiazm nadający całej strukturze emfazę, większą dynamikę, w której bracia Dawida, przedstawieni w bardzo pozytywny sposób od strony fizycznej, nie spełniają warunków do tego, aby być namaszczonymi i wywyższonymi. Ostatnie dwa bikolony w 10. wersie tworzą (podobnie jak w 1.) paralelizm synonimiczny ${ }^{64}$. Powyższa struktura i korelacja pomiędzy jej poszczególnymi elementami wykazuje w tekście ważne wnioski teologiczne. Wers 1., mówiący o wyglądzie Dawida i jego funkcji jako pasterza nad stadem Jessego, znajduje swój odpowiednik w wersie 10., gdzie widać wyraźny kontrast i rozwój myśli autora. Młody wiek i mało znacząca funkcja nie są przeszkodą do tego, aby Dawid mógł odegrać rolę lidera nad całym Izraelem. Wyraźnie podkreśla to 2. bikolon wersu 1. וישימני רועה לצונו ומושל בגדיותיו i 2. bikolon wersu 10. Ten sam czasownik użyty w identycznej formie w obu przypadkach odnosi się do ustanowienia, nadania funkcji Dawidowi, jednak w wersie 1. tę funkcję nadaje Jesse i dotyczy ona władzy nad zwierzętami, w ostatnim władza pochodzi z Bożego nadania i rozciąga się na ludzi.

Wers 2. kontynuuje narrację 1. i mówi o pracy Dawida nad wytworzeniem instrumentów muzycznych, które mają mu posłużyć do wychwalania Boga. Koresponduje z wersem 9., gdzie autor przedstawia braci Dawida, którzy polegając tylko na swoich walorach fizycznej budowy, nie zostają wybrani. Widać tu kontrast pomiędzy Dawidem, który nie spodziewa się wyboru, gdyż jego główną intencją jest wychwalanie Pana, a braćmi zbyt mocno przekonanymi o swoich zaletach.

Wers 3. kontynuujący opowiadanie dwóch pierwszych ukazuje to, co się dzieje we wnętrzu Dawida i może być zestawiony z wersem 8 . Takie porównanie podkreśla kontrast pomiędzy ukrytymi cnotami Dawida a widocznymi przymiotami pozostałych synów Jessego.

Wers 4. wyrażający pewien smutek Dawida ze względu na jego obecną sytuację łączy się z 7., w którym pojawia się nadzieja na odmianę jego rzeczywistości przez misję Samuela, jako wykonawcy planu Bożego względem jego osoby.

Centrum utworu stanowią wersy 5. i 6. będące ze sobą najmocniej powiązane. Wers 5. stawia trzy pytania, a 6. daje odpowiedź. Oba wchodzą w skład

65 Segal, „The Literary Developement of Psalm 151”, 157. 
modlitwy Dawida, możemy powiedzieć, że całość narracji zmierza ku tej części, natomiast dalsza treść jest jej pochodną. Pytania: kto ogłosi, kto opowie i kto zliczy dzieła Pana, pokazują mocną zażyłość pomiędzy Bogiem a Dawidem, który w potrójnej odpowiedzi pokazuje swoją zależność wobec wszechmocnego działania Boga w jego życiu ${ }^{66}$.

\subsection{Tekst hebrajski Psalmu 151b (11QPs $\left.{ }^{\mathrm{a}}\right)$ wraz z polskim tłumaczeniem (kolumna tabelka)}

\begin{tabular}{|c|c|}
\hline בריתו Cezura & 12 \\
\hline תחלת גב]י[רה ל]דו[יד משמשחו נביא אלוהים אזי רא]י[תי פלשתי & 13 \\
\hline מחרף מ[מערכות פלשתים] אנוכי [...] את [...] & 14 \\
\hline
\end{tabular}

13 Początek mocy Dawida po tym jak namaścił go Boży prorok. Wtedy zobaczyłem Filistyna

14 wydającego wyzwanie z szeregów Filistynów. Ja...

\subsection{Analiza tekstu}

Dwie ostatnie linie 13. i 14. w kolumnie XXVIII są zachowane w zwoju bardzo fragmentarycznie. Cały Psalm 151a i poprzedzające go dwie linie wchodzące w skład Psalmu 134 zachowały się w nienaruszonym stanie, czego nie można powiedzieć o Psalmie 151b. Utwór ten jawi się jako fizycznie odrębny tekst znajdujący się na samym dole kolumny XXVIII, na co wskazuje układ tekstu i jego syntaksa. Po pierwsze, końcówka zwoju uwydatnia przerwę pomiędzy Psalmem 151a i 151b. W całym zwoju nie ma takiego wypadku, aby autor urywał jednolity tekst w połowie linii i przenosił dalszą treść do nowej. Takie wypadki są tylko wtedy, gdy skryba rozpoczyna nową kompozycję. Po drugie, na odrębny utwór wskazuje badanie syntaktyczne. W Psalmie 151a po tytule w linii 3. narracja jest wyrażona w 1. os. 1. poj., w omawianym tekście autor zrywa ten sposób wyrażania myśli, przechodząc do 3. os. 1. poj. r. m. Co więcej, początkowy fragment z kolumny 13. תחלת גב[י]רה ל[די[יד משמשחו נביא אלוהים jest tytułem nowej kompozycji, identycznie jak w Psalmie 151a. W opinii E. van

66 Storfjell, „The Chiastic Structure of Psalm 151”, 104-106.

67 Sanders, The Psalms Scroll of Qumran Cave 11, 60; Garcia Martinez - Tigchelaar, The Dead Sea Scrolls. Study Edition, 1178. 
Rooya i J. VanderKama psalm mógł początkowo istnieć jako tekst jednolity, ale jedność ta została złamana dla uwydatnienia elekcji Dawida połączonej z namaszczeniem (151a) i jego walki z Goliatem ${ }^{68}$. Opinia ta jest słuszna, gdyż choć fizycznie układ w zwoju świadczy o odrębności między utworami, to treściowo widać ciągłość pomiędzy nimi. Gdy pominiemy zupełnie tytuł Psalmu 151b, narracja wraca do 1. os. 1. poj. i podobnie jak w 1 Księdze Samuela, do której odnoszą się Psalmy 151a i b, po wyborze i namaszczeniu Dawida w 16. rozdziale, następuje szczegółowy opis walki z Goliatem w rozdziale 17.

Ostatnie 2 linie kolumny XXVIII możemy uznać, podobnie jak Psalm 151a, jako midrasz do 17. rozdziału 1 Księgi Samuela. Tytuł omawianej kompozycji, rozpoczynający linię 13., pokazuje stan Dawida po namaszczeniu przez proroka. W wyrażeniu תחלת גב[1][רה ל]די[ו] ,początek mocy Dawida” widać łańcuch status constructus, który mimo braku rodzajnika przy pierwszym członie, jest określony przez drugi, będący imieniem własnym ידיז], wprowadzony przez partykułę ל, która służy w tym wypadku jako formant genetiwu. Syntaktycznie ten opisowy status constructus łączy się z drugą częścią tytułu, którą jest zdanie werbalne i w stosunku do niego ma sens skutkowy, a więc moc Dawida, której obecnie doświadcza, wynika $\mathrm{z}$ faktu uprzedniego namaszczenia go przez proroka Bożego, co wyraża synatgma משמשחו (partykuła min + she + infinitivus constructus + sufix 3. os. 1. poj. r. m.).

Użycie w tekście rzeczownika גבריה - , siła, moc, potęga” - może być przez nas wyjaśnione dzięki narracji 1 Sm 16,18, w której po scenie namaszczenia, przebywając na dworze królewskim, Dawid jest scharakteryzowany przez jednego z dworzan Saula jako גבור חיל ואיש מלחמה ונבון דבר ואיש תאר ויהוה עמו -,dzielny wojownik i mąż wojny (zaprawiony w boju), bystry w słowie, mężczyzna piękny, bo Pan jest z nim". Tak więc siła, moc, bystrość i piękno mają swój fundament w obecności i bliskości Boga w życiu Dawida. Tę bliskość objaśnia dokładniej werset 13. przywołanego rozdziału 1 Księgi Samuela, z którego relacji dowiadujemy się, że bezpośrednio po namaszczeniu Duch Pański opanował Dawida .

Od drugiej połowy linii 13. narracja, podobnie jak w tekście omówionym wcześniej, przechodzi z 3. os. 1. poj. r. m. do 1. os. 1. poj., którą uwydatnia zdanie: whtedy zobaczyłem Filistyna wydającego wyzwanie”. Jest to zdanie werbalne, w którym podmiot jest wyrażony przez zrekonstruowany czasownik ראה ,widzieć” w formie perfectum 1. os. 1. poj. w koniugacji Qal,

68 Sanders, The Psalms Scroll of Qumran Cave 11, 60; Garcia Martinez - Tigchelaar, The Dead Sea Scrolls. Study Edition, 1178; H.F. van Rooy, Studies on the Syriac Apocryphal Psalms (JSSSup 7; Oxford: Oxford University Press 1999) 109; VanderKam, The Dead Sea Scrolls and the Bible, 94.

69 Sanders, The Psalms Scroll of Qumran Cave 11, 60. 
natomiast wyrażenie: פלשתי מחרף pełni funkcję akusatiwu w funkcji dopełnienia bliższego. Analizując accusativus dokładniej, możemy zauważyć participium r. m. 1. poj. w koniugacji Piel od czasownika חרף -,robić wymówki”; w tym wypadku użyty imiesłów pełni funkcję przydawki. Co ciekawe, całe zdanie poprzedza przysłówek czasowy אזי, - ,wtedy”, wprowadzony przez autora po to, aby uwypuklić w narracji pewną emfazę ${ }^{70}$, podkreślić moment samego spostrzeżenia przez Dawida osoby i działań Filistyna. Całe to zdanie jest mocno

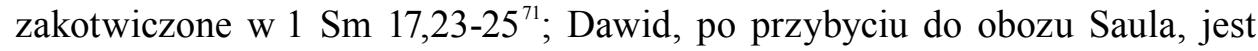
świadkiem wystąpienia Goliata wygłaszającego pod adresem wojsk izraelskich urągające słowa. Pomiędzy treścią psalmu a orędziem $1 \mathrm{Sm} \mathrm{17,23} \mathrm{tkwi} \mathrm{subtelna}$ różnica percepcji Filistyna przez Dawida. Autor dzieła deuteronomistycznego, w 23. wersecie relacjonuje, iż Dawid ,usłyszał” słowa Filistyna, co oddaje przez odwróconą formę imperfectum 3. os. 1. poj. r. m. w koniugacji Qal.

W Psalmie $151 \mathrm{~b}$ autor kładzie nacisk nie tyle na zmysł słuchu, ile na wzrok תי[י][', , zobaczyłem”. Tak wyrażona treść może stanowić odwołanie do namaszczenia, które dało Dawidowi wielkość i siłę, a więc dzięki tej mocy potrafi on stawić czoła człowiekowi, który samym tylko wyglądem wzbudza strach. Jednocześnie forma z psalmu stoi w kontraście do wersetu 24. z 1 Sm 17, w którym wojsko izraelskie, widząc swego przeciwnika, zostało ogarnięte strachem.

Interpretacja drugiej połowy 14. linii jest niemożliwa ze względu na fragmentaryczność tekstu. Możemy podjąć próbę rekonstrukcji wersji hebrajskiej na podstawie tekstu greckiego z Septuaginty, co zrobił M. Segal ${ }^{72}$, ale będzie to działanie czysto hipotetyczne, ponadto wersja hebrajska Psalmu 151b ma zupełnie inny przekaz treściowy niż tekst grecki, a jedynym elementem stycznym obu wersji jest motyw walki z Filistynem.

\section{Konkluzja}

Tekst Psalmu 151 w wersji hebrajskiej znajduje się tylko w zwoju psalmów 11Q5. Pod względem budowy literackiej jest utworem starannie opracowanym, z widoczną w liniach 7. i 8. inkluzją. Od innych utworów zwoju i tekstów biblijnych odróżnia go narracja w 1. os. 1. poj.; narrator (Dawid) jest jednocześnie podmiotem i przedmiotem w całej kompozycji, która z każdą linią ulega rozwojowi myśli teologicznej. Dawid, będąc najmłodszym, najmniej znaczącym synem Jessego, dzięki Bożej interwencji stał się władcą nad całym Izraelem.

70 Waltke - O'Connor, An Introduction, 667-668.

71 Sanders, The Psalms Scroll of Qumran Cave 11, 61.

72 Segal, „The Literary Developement of Psalm 151”, 145. 
Tak pojmowana teologia ma swoje zakorzenienie w rozwoju myśli mesjanizmu biblijnego, znajdującego swoje dopełnienie w przepowiadaniu apostolskim. Sam zwój jest dziełem z I w. przed Chrystusem, natomiast data powstania psalmu przesuwa się do epoki hellenistycznej czy nawet wcześniej, na czas epoki perskiej. Za taką datacją świadczy struktura, styl i język charakterystyczny dla tekstów powstałych w tym czasie. Psalm, jak powiedzieliśmy wcześniej, pierwotnie mógł istnieć jako jeden, nierozłączny utwór, podzielony przez autora manuskryptu na dwie części ze względów teologicznych. Jest to słuszne założenie, gdyż analiza jednego słowa z tytułu Psalmu 151b משמשחו wskazuje na zupełnie odrębny styl od całej kompozycji, charakterystyczny dla języka hebrajskiego rabinicznego.

\section{Bibliografia}

Bergman, J. - Ringgren, H. - Haag, H., „בן", Theologisches Wörterbuch zum Alten Testament (red. G.W. Anderson - H. Cazelles - D.N. Freedman - S. Talmon - G. Wallis) (Stuttgart Berlin - Koln-Mainz: Verlag 1972) I, 668-682.

Bjornar Storfjell, J., „The Chiastic Structure of Psalm 151”, Andrews University Seminary Studies 25 (1987) 97-106.

Dahmen, U., Psalmen - und Psalter rezeption im Fruhjudentum. Rekonstruktion, Textbestand, Struktur und Pragmatik der Psalmenrolle 11QPs ${ }^{a}$ aus Qumran (Leiden - Boston: Brill 2003).

Dimant, D., „David's Youth in the Qumran Contekst (11QPsa 28, 3-12)”, Prayer and Poetry in the Dead Sea Scrolls and Related Literature. Essays in Honor Eileen Schuller on the Occasion of Her 65th Birthday (red. J. Penner - K.M. Penner - C. Wassen) (Leiden - Boston: Brill 2012) $97-115$.

Farutin, A., „Tekst Psalmu 151 w rękopisie 11Q5 z Qumran i w Septuagincie. Problem ustalenia pierwotnej redakcji”, Collectanea Theologica 85/1 (2015) 67-94.

Fitzmyer, A.J., The Dead Sea Scrolls and the Christian Origins (Grand Rapids, MI: W.B. Erdmans 2000).

Flint, P., The Bible at Qumran. Text, Shape and Interpretation (Grand Rapids, MI - Cambridge: W.B. Eerdmans 2001).

Flint, W. P. - Ulrich E., Qumran Cave 1.II: The Isaiah Scrolls (Discoveries in the Judaean Desert XXXII; Oxford: Clarendon 2010).

---------, „Psalms and Psalters in the Dead Sea Scrolls”, The Bible and the Dead Sea Scrolls. Scripture and the Scrolls I: The Second Princeton Symposium on Judaism and Christian Origins (red. J.H. Charlesworth) (Waco, TX: Baylor University Press 2006) 233-273.

--------, The Dead Sea Psalms Scrolls and the Book of Pslams (STDJ 17; Leiden - New York - Koln: Brill 1997).

Garcia Martinez, F. - Tigchelaar, C.J.E., The Dead Sea Scrolls. Study Edition (Leiden - New York - Koln: Brill 1999) I.

Hossfeld, L.F. - Zenger, E., Psalmen 51-100 (Herders Theologischer Kommentar zum Alten Testament; Freiburg - Basel - Wien: Herder 2000).

Koehler, L. - Baumgartner, W. - Stamm, J.J., The Hebrew and Aramaic Lexicon of the Old Testament (Leiden - New York - Koln: Brill 1994). 
Kowalski, A., „Psalmy 151-155 (syryjskie psalmy apokryficzne 1-5)”, Warszawskie Studia Teologiczne VII (1994) 21-28.

Magness, J., The Archaeology of Qumran and the Dead Sea Scrolls (Grand Rapids, MI: W.B. Erdmans 2002).

Muchowski, P., Rękopisy znad Morza Martwego: Qumran - Wadi Murabbaat-Masada - Nachal Chewer (Biblioteka Zwojów: Tło Nowego Testamentu; Kraków: The Enigma Press, 2000).

Rendtorff, R., „The Psalms of David: David in the Psalms”, The Book of Psalms. Composition and Reception (red. P.W. Flint - P.D. Miller) (Leiden - Boston: Brill 2005) 53-64.

Reymond, D.E., New Idioms within Old. Poetry and Parallelism in the Non-Masoretic Poems of $11 Q 5\left(=11 Q P s^{a}\right)$ (Society of Biblical Literature. Early Judaism and Its Literature 31; Atlanta: Scholars Press 2011).

----------, Qumran Hebrew. An Overviev of Orthography, Phonology, and Morphology (Society of Biblical Literature 76; Atlanta: Scholars Press 2014).

Sanders, A.J., The Psalms Scroll of Qumran Cave $11\left(11 Q P s^{a}\right)$ (Discoveries in the Judaean Desert of Jordan IV; Oxford: Clarendon Press 1965).

Segal, M., „The Literary Developement of Psalm 151: A New Look at the Septuagint Version”, Textus 21 (2002) 139-158.

Tov, E., Textual Criticism of the Hebrew Bible (Second Revised Edition; Minneapolis - Assen: Fortress - Royal van Gorcum 2001).

---------, Textual Criticism of the Hebrew Bible, Qumran, Septuagint. Collected Essays (Supplements to Vetus Testamentum 167; Leiden - Boston: Brill 2015) III.

Tronina, A., „Psalm 151 - Poetycki midrasz do dziejów Dawida”, Roczniki Teologiczne XLIII/1 (1996) 81-87.

Ulrich, E., The Dead Sea Scrolls and the Developmental Composition of the Bible (Supplements to Vetus Testamentum 169; Leiden - Boston: Brill 2015).

Van Rooy, F.H., Studies on the Syriac Apocryphal Psalms (Supplements to the Journal of Semitic Studies 7; Oxford: Oxford University Press 1999).

VanderKam, C.J., Manuskrypty znad Morza Martwego (Warszawa: Wydawnictwo Cyklady 1996).

VanderKam, J. - Flint P., The Meaning of the Dead Sea Scrolls. Their Significance for Understanding the Bible, Judaism, Jesus, and Christianity (New York: Harper Collins Publishers 2002).

Waltke, K.B. - O'Connor M., An Introduction to Biblical Hebrew Syntax (Winiona Lake: Eisenbrauns 1990).

Watson, E.G.W., Classical Hebrew Poetry. A Guide to its Techniques (Journal for the Study of the Old Testament Supplement Series 26; Sheffield: JSOT Press 1986).

Witt, C.A., „David, the «Ruler of the Sons of His Covenant» [...]: The Expansion of Psalm 151 in 11QPsa”, Journal for the Evangelical Study of the Old Testament 3/1 (2014) 77-97.

Zawadzki, A., „Nowe thumaczenie i interpretacja Iz 55,3-5. Studium egzegetyczno-historyczne”, Biblical Annals 7/1 (2017) 49-85. 